FEDERAL RESERVE BANK OF SAN FRANCISCO

WORKING PAPER SERIES

\title{
State Investment Tax Incentives: What Are the Facts?
}

\author{
Robert S. Chirinko \\ Emory University and CESifo \\ and \\ Daniel J. Wilson \\ Federal Reserve Bank of San Francisco
}

November 2006

Working Paper 2006-49

http://www.frbsf.org/publications/economics/papers/2006/wp06-49bk.pdf

The views in this paper are solely the responsibility of the authors and should not be interpreted as reflecting the views of the Federal Reserve Bank of San Francisco or the Board of Governors of the Federal Reserve System. This paper was produced under the auspices for the Center for the Study of Innovation and Productivity within the Economic Research Department of the Federal Reserve Bank of San Francisco. 


\title{
State Investment Tax Incentives: What Are the Facts?
}

\author{
Robert S. Chirinko \\ (Emory University and CESifo) \\ and \\ Daniel J. Wilson \\ (Federal Reserve Bank of San Francisco)
}

November 6, 2006

Paper Prepared for the session

"Are State Business Tax Incentives Good Public Policy? Multi-Disciplinary Perspectives in the Wake of Cuno v. DaimlerChrysler"

National Tax Association's

$99^{\text {th }}$ Annual Conference on Taxation

Boston, MA

November $16^{\text {th }}$ to $18^{\text {th }}, 2006$

* The authors would like to thank Ann Lucas and Charles Notzon for excellent research assistance. The first author gratefully acknowledges financial support from the Federal Reserve Bank of San Francisco. All errors and omissions remain the sole responsibility of the authors, and the conclusions are not necessarily shared by the organizations with which they are affiliated. 


\title{
State Investment Tax Incentives: What are the Facts?
}

\begin{abstract}
There is an ongoing debate in the U.S. among policymakers and the courts concerning the practical effects of state investment tax incentives. However, this debate often suffers from a lack of clear information on the extent of such incentives among states and how these incentives have evolved over time. This paper takes a first step toward addressing this shortcoming. Compiling information from all fifty states and the District of Columbia over the past 40 years, we are able to paint a picture of the variation in state investment tax incentives across states and over time. In particular, we document 3 stylized facts: (1) Over the last forty years, state investment tax incentives have become increasingly large and increasingly common among states; (2) These incentives, as well as the level of the overall after-tax price of capital, are to a large extent clustered in certain regions of the country; and (3) States that enact investment tax credits tend to do so around the same time as their neighboring states.
\end{abstract}

Robert S. Chirinko

318 Rich Building

Department of Economics

Emory University

Atlanta, GA 30322-2240

PH: (404) 727-6645

FX: (404) 727-4639

EM: Robert.Chirinko@emory.edu
Corresponding Author:

Daniel J. Wilson

Research Department

Federal Reserve Bank of

San Francisco

101 Market Street

San Francisco, CA 94105

PH: (415) 974-3423

FX: (415) 974-2168

EM: Daniel.Wilson@sf.frb.org 


\section{State Investment Tax Incentives: What are the Facts?}

\section{Introduction}

In the late 1990s, the automaker DaimlerChrysler faced a major decision - expand and upgrade its existing Jeep assembly plant in Toledo, Ohio or replace it with a new plant located elsewhere. In order to keep DaimlerChrysler's Jeep production in Toledo and in Ohio, state and city officials in 1998 put together a package of tax incentives for the company valued at \$280 million. The package consisted of a newly-enacted local property tax exemption exclusively for the Jeep facility and an existing investment tax credit against the state corporate income tax. Though it is not widely acknowledged, the investment tax credit, in fact, already was on the books since 1995 and was not a tax measure passed specifically for DaimlerChrysler (or any other single company).

This tax incentive package led to a legal challenge, Cuno, et al. v. DaimlerChrysler, et al., against Toledo, Ohio, and DaimlerChrysler. The case eventually made its way to the U.S. Supreme Court in 2005-2006 after the Sixth Circuit Federal Court of Appeals ruled that Ohio’s investment tax credit ran afoul of the so-called dormant Commerce Clause of the U.S. Constitution. (Note this case is discussed in much greater detail in Enrich (2006, NTA proceedings) and in Stark and Wilson (2005)). The “dormant” or "negative” Commerce Clause is a doctrine inferred by the U.S. Supreme Court from the Commerce Clause (clause 3) in Article I, Section 8 of the U.S. Constitution, which empowers the U.S. Congress to regulate interstate commerce. The inference is that, because the Commerce Clause explicitly grants the U.S. Congress the power to enact legislation pertaining to interstate commerce, the Constitution 
implicitly bars states and localities from doing so. For whatever reason, the Supreme Court traditionally has restricted its dormant Commerce Clause jurisprudence to tax statutes.

In the Cuno case, the Sixth Circuit reasoned that, since a tax credit is no different than an income tax (with a negative rate) and thus Ohio's ITC effectively taxes an Ohio-sited company differently depending on whether it chooses to invest in-state or out-of-state, the credit violates the dormant Commerce Clause.

The Supreme Court agreed to hear this case in 2006. However, it did not address the merits of the case but instead ruled that the plaintiffs did not have standing in federal court - i.e., the plaintiffs should have initiated the case in state court rather than federal court. Thus, the constitutionality of state investment tax credits remains very much an open question. While the Cuno case itself is headed back to state court in Ohio, a number of other, similar cases are currently before the courts in other parts of the U.S..

Of central importance to the legal debate is whether such tax credits and other statewide tax incentives do, in fact, adversely impact out-of-state economic activity. For instance, in the Supreme Court case Bacchus Imports v. Dias, the majority wrote that a tax provision violates the dormant Commerce Clause if the provision "will in its practical operation work discrimination against interstate commerce,..., by providing a direct commercial advantage to local business” (Bacchus Imports v. Dias, 468 U.S. 1984) (italics added). ${ }^{1}$

Of course, the in-state and out-of-state impacts of tax incentives are not only important to the courts, but also is of central importance to policymakers. State policymakers are guided by

\footnotetext{
${ }^{1}$ Curiously, the case law on the dormant Commerce Clause is limited to considerations of the validity of taxes, credits, or exemptions on specific, targeted activities, but never has addressed the issue of whether the corporate income tax itself violates the clause. This point was noted in Stark and Wilson (2005): “There has never been any suggestion in Cuno or elsewhere that a state choosing to lower its overall business tax burden would face any Commerce Clause restraints in choosing to do so, even if such a policy change would lead businesses to relocate from one state to another."
} 
economic studies as to the effectiveness of these incentives in stimulating economic activity within their state and whether their state faces economic harm from tax incentives enacted in other states. National policymakers also are keenly interested in knowing the in-state and out-ofstate costs and benefits of these tax incentives. For instance, in the last several years, there have been a number of bills proposed in Congress that would affect the ability of states to enact these incentives. Unfortunately, though, there has been very little economic research into the in-state vs. out-of-state effects of state tax incentives. The primary reason, we believe, is a lack of data, both on economic activity and on state tax policy.

This paper takes a first step toward addressing this shortcoming by investigating the nature of the variation in state investment tax incentives. Compiling information from all fifty states and the District of Columbia over the past 40 years, we are able to paint a picture of the variation in state investment tax incentives across states and over time. Specifically, we document 3 facts:

1. Over the last forty years, state investment tax incentives have become increasingly large and increasingly common among states,

2. These incentives, as well as the level of the overall after-tax price of capital, are to a large extent clustered in certain regions of the country

3. States that enact investment tax credits tend to do so around the same time as their neighboring states.

Before proceeding with our investigation of state tax incentives, it is important that we be clear as to the scope of our investigation. We focus here on general, statewide investment tax incentives such as increases in investment tax credits (ITCs) or reductions in the corporate 
income tax. We abstract from narrowly targeted state incentives such as those targeted toward particular localities (e.g., “enterprise zones”) or specific industries because such incentives have little impact on the overall business tax climate for a state as a whole. Given our focus on investment incentives, we also exclude from our analysis tax incentives targeted solely at job creation; approximately 20 states have a general, statewide job creation tax credit in 2004 . Lastly, we ignore tax incentives targeted at specific companies, such as those aimed at landing high-profile plants of foreign automakers. ${ }^{2}$ While these plant-specific incentives receive much press attention, the investment they potentially elicit is, quantitatively, at most a very small share of statewide investment. For example, the largest investment in recent years associated solely with targeted tax incentives that we are aware of is the \$550 million plant that Honda reportedly will begin building in 2006 in Greensburg, Indiana. While this investment may seem large, it is actually rather quite small relative to the $\$ 5.2$ billion of investment done by manufacturers in Indiana in the most recent year of available data (2004, Annual Survey of Manufacturers) and given that \$550 million will be spread out over several years.

The remainder of this paper is organized as follows. Section 2 describes the data we have constructed on state investment tax incentives from 1964 - 2004. A detailed description of the cross-state and cross-time variation in these incentives is presented in Section 3. Section 4 concludes.

\footnotetext{
${ }^{2}$ Note the Ohio ITC at issue in the Cuno v. DaimlerChrysler case does not fit in this category because, as mentioned above, the ITC is available to all businesses with qualified investment in Ohio.
} 


\section{Data}

The focus of this paper is on state tax policy related to business investment.

Conceptually, we want to capture the elements of state tax policy that affect the after-tax price of capital faced by a business in a given state. The Neoclassical formulation of the after-tax price of capital, often referred to as the user cost of capital, was introduced by Hall and Jorgenson (1967) and has been further developed and expanded upon by, among others, King and Fullerton (1984), Gravelle (1994), and Jorgenson and Yun (2001). The basic formula for the user cost of capital for state $\mathrm{s}$ at time $\mathrm{t}$ is as follows,

$$
\mathrm{UC}_{\mathrm{s}, \mathrm{t}}=\mathrm{PRICE}_{\mathrm{t}} * \mathrm{OPPCOST}_{\mathrm{t}} * \mathrm{TAX}_{\mathrm{s}, \mathrm{t}} \cdot
$$

This series is defined as the product of three terms. The first term ( $\left.\mathrm{PRICE}_{t}\right)$ is the purchase price of a capital good relative to the price of output. The second term ( $\left.\mathrm{OPPCOST}_{t}\right)$ is the opportunity cost of holding depreciating capital. ${ }^{3}$ The third term $\left(\operatorname{TAX}_{\mathrm{s}, \mathrm{t}}\right)$, which we will refer to as the "tax wedge," captures the corporate income tax rate as well as the value of tax credits and deductions. Notice that the tax wedge is the ratio of the after-tax price of capital $\left(\mathrm{PRICE}_{\mathrm{t}} * \mathrm{OPPCOST}_{\mathrm{t}} * \mathrm{TAX}_{\mathrm{s}, \mathrm{t}}\right)$ and pre-tax price of capital $\left(\mathrm{PRICE}_{\mathrm{t}} * \mathrm{OPPCOST}_{\mathrm{t}}\right)$. The tax wedge essentially serves as a summary statistic of the extent of taxation imposed on capital in a given state and hence is our primary variable of interest. Following Hall and Jorgenson (1967) and others, we define the tax wedge as follows,

\footnotetext{
${ }^{3}$ The opportunity cost of capital depends on the state income tax rate because of the tax-deductibility of interest payments. This state-dependent feature of the tax code has a small effect on the opportunity cost, and hence the s subscript has been omitted.
} 


$$
\mathrm{TAX}_{\mathrm{s}, \mathrm{t}}=\left(1-\mathrm{ITC}_{\mathrm{s}, \mathrm{t}}^{\mathrm{S}}-\mathrm{ITC}_{\mathrm{t}}^{\mathrm{F}}-\left(\tau_{\mathrm{s}, \mathrm{t}}^{\mathrm{E}, \mathrm{S}}+\tau_{\mathrm{s}, \mathrm{t}}^{\mathrm{E}, \mathrm{F}}\right) \mathrm{TD}_{\mathrm{t}}\right) /\left(1-\left(\tau_{\mathrm{s}, \mathrm{t}}^{\mathrm{E}, \mathrm{S}}+\tau_{\mathrm{s}, \mathrm{t}}^{\mathrm{E}, \mathrm{F}}\right)\right)
$$

where $\operatorname{ITC}_{\mathrm{s}, \mathrm{t}}^{\mathrm{S}}$ and $\mathrm{ITC}_{\mathrm{t}}^{\mathrm{F}}$ are the legislated investment tax credit rates at the state and federal levels, respectively, $\tau_{\mathrm{s}, \mathrm{t}}^{\mathrm{E}, \mathrm{S}}$ and $\tau_{\mathrm{t}}^{\mathrm{E}, \mathrm{F}}$ are the effective corporate income tax rates at the state and federal levels, respectively, $\mathrm{TD}_{\mathrm{t}}$ is the present value of tax depreciation allowances. (In the current, preliminary draft of this paper, $\mathrm{TD}_{\mathrm{t}}$ is simply set equal to a constant of 0.7.)

We measure the components of the tax wedge using a variety of data sources. The state investment tax credit rates, $\mathrm{ITC}_{\mathrm{s}, \mathrm{t}}^{\mathrm{S}}$ were obtained directly from states' online corporate tax forms and instructions. For most states with an investment tax credit, both current and historical credit rates are provided in the current year instructions (since companies applying for a credit based on some past year's investment apply that year's credit rate rather than the current rate). In those few cases where some or all historical rates were missing from the online forms and instructions, the missing rates are obtained via direct communication with the state's department of taxation. In some states, the legislated investment tax credit rate varies by the level of capital expenditures; we use the legislated credit rate for the highest tier of capital expenditures.

The effective corporate income tax rate at the state level, $\tau_{\mathrm{s}, \mathrm{t}}^{\mathrm{E}, \mathrm{S}}$, is lower than the legislated (or statutory) corporate income tax rate,$\tau_{\mathrm{s}, \mathrm{t}}^{\mathrm{L}, \mathrm{S}}$, due to the deductibility (in some states) against state taxable income of taxes paid to the federal government. ${ }^{4}$ Some states allow full deductibility of federal corporate income taxes from state taxable income, Iowa and Missouri allow only 50\% deductibility, and some states allow no deductibility at all. The deductibility

\footnotetext{
${ }^{4}$ Some states refer to their corporate income taxes as "franchise" or "excise" taxes.
} 
provision in state tax codes is represented by $v_{\mathrm{s}, \mathrm{t}}=\{1.0,0.5,0.0\}$, and the provisional effective corporate income tax rate at the state level is as follows,

$$
\tau_{\mathrm{s}, \mathrm{t}}^{\#, \mathrm{~S}}=\tau_{\mathrm{t}}^{\mathrm{L}, \mathrm{S}}\left(1-\tau_{\mathrm{s}, \mathrm{t}}^{\#, \mathrm{E}, \mathrm{F}} \mathrm{U}_{\mathrm{s}, \mathrm{t}}\right)
$$

The effect of federal income tax deducibility is represented by the provisional effective corporate income tax rate at the federal level (defined below).

The $\tau_{\mathrm{s}, \mathrm{t}}^{\mathrm{L}, \mathrm{S}}$ and $v_{\mathrm{s}, \mathrm{t}}$ series are obtained from several sources. For recent years, data are obtained primarily from various issues of Book of the States (Council of State Governments) and State Tax Handbook (Commerce Clearing House), as well as actual state tax forms. Data for earlier years are obtained from various issues of Book of the States and Significant Features of Fiscal Federalism (American Council on Intergovernmental Affairs). Additional information has been provided by the Tax Foundation website (see Tax Foundation in References). Many states have multiple legislated tax rates that increase stepwise with taxable income; we measure $\tau_{\mathrm{t}, \mathrm{S}}^{\mathrm{L} S}$ with the marginal legislated tax rate for the highest income bracket.

Similarly, the effective corporate income tax rate at the federal level is lower than the legislated corporate income tax rate $\left(\tau_{\mathrm{t}, \mathrm{s}}^{\mathrm{L}, \mathrm{F}}\right)$ due to the deductibility against federal taxable income of taxes paid to the state. The provisional effective corporate income tax rate at the federal level is as follows,

$$
\tau_{\mathrm{s}, \mathrm{t}}^{\mathrm{\#}, \mathrm{E}, \mathrm{F}}=\tau_{\mathrm{t}}^{\mathrm{L}, \mathrm{F}}\left(1-\tau_{\mathrm{s}, \mathrm{t}}^{\#, \mathrm{~S}}\right)
$$


It has not generally been recognized that, owing to deductibility of taxes paid to another level of government, the effective corporate income tax rates at the state and federal levels are functionally related to each other. As shown in the above equations, these interrelationships yield two equations in two unknowns and thus can be solved for the effective corporate income tax rates at the state and federal levels, respectively, as follows,

$$
\begin{aligned}
& \tau_{\mathrm{s}, \mathrm{t}}^{\mathrm{E}, \mathrm{S}}=\tau_{\mathrm{s}, \mathrm{t}}^{\mathrm{L}, \mathrm{S}}\left[1-\mathrm{v}_{\mathrm{s}, \mathrm{t}} \tau_{\mathrm{t}}^{\mathrm{L}, \mathrm{F}}\right] /\left[1-\mathrm{v}_{\mathrm{s}, \mathrm{t}} \tau_{\mathrm{s}, \mathrm{t}}^{\mathrm{L}, \mathrm{S}} \tau_{\mathrm{t}}^{\mathrm{L}, \mathrm{F}}\right], \\
& \tau_{\mathrm{s}, \mathrm{t}}^{\mathrm{E}, \mathrm{F}}=\tau_{\mathrm{t}}^{\mathrm{L}, \mathrm{F}}\left[1-\tau_{\mathrm{s}, \mathrm{t}}^{\mathrm{L}, \mathrm{S}}\right] /\left[1-\mathrm{v}_{\mathrm{s}, \mathrm{t}} \tau_{\mathrm{s}, \mathrm{t}}^{\mathrm{L}, \mathrm{S}} \tau_{\mathrm{t}}^{\mathrm{L}, \mathrm{F}}\right] .
\end{aligned}
$$

The overall corporate income tax rate is the sum of $\tau_{\mathrm{s}, \mathrm{t}}^{\mathrm{E}, \mathrm{S}}$ and $\tau_{\mathrm{s}, \mathrm{t}}^{\mathrm{E}, \mathrm{F}}$. In the limiting case where federal corporate income taxes are not deductible against state taxable income $\left(v_{s, t}=0\right)$, this sum reduces to the more frequently used formula, $\tau_{\mathrm{s}, \mathrm{t}}^{\mathrm{L}, \mathrm{S}}+\tau_{\mathrm{t}}^{\mathrm{L}, \mathrm{F}}-\tau_{\mathrm{s}, \mathrm{t}}^{\mathrm{L}, \mathrm{S}} * \tau_{\mathrm{t}}^{\mathrm{L}, \mathrm{F}}$.

There are three caveats on the data that should be noted. First, local property taxes also affect the true after-tax price of capital and hence the state tax wedge. However, we do not consider these taxes in this paper both for data availability reasons and because states in general do not directly control local tax policy. Hence excluding property taxes provides a better picture of state-controlled tax policy. Second, we do not account for state differences in the apportionment formulae used to allocate a business's federal taxable income among states. Properly incorporating a state's apportionment formula into the after-tax price of capital requires information that is not available such as the geographic distribution of property, payroll, and sales for businesses operating in the state. Third, we purge our state tax wedge variable of the 
effect of federal tax policies, such as the federal investment tax credit, which existed from 1962 to 1986, and the federal corporate income tax, since our focus in this paper is on the cross-state and cross-time variation in state tax policies. Including federal tax components, while having little effect on between-state comparisons ${ }^{5}$, would dominate the time series movements in the state tax wedge and hence obscure the trends in state tax policy over time. Specifically, we set

$\mathrm{ITC}_{\mathrm{t}}^{\mathrm{F}}=0$ and $\tau_{\mathrm{s}, \mathrm{t}}^{\mathrm{E}, \mathrm{F}}=0$ in equation (1) above. Imposing these restrictions yields the following formula for the state tax wedge ,

$$
\mathrm{TAX}_{\mathrm{s}, \mathrm{t}}=\left(1-\mathrm{ITC}_{\mathrm{s}, \mathrm{t}}^{\mathrm{S}}-\tau_{\mathrm{s}, \mathrm{t}}^{\mathrm{E}, \mathrm{S}} \mathrm{TD}_{\mathrm{t}}\right) /\left(1-\tau_{\mathrm{s}, \mathrm{t}}^{\mathrm{E}, \mathrm{S}}\right)
$$

\section{Some Stylized Facts About State Investment Tax Policy Over The Past 40 Years}

As described in the previous section, the tax ramifications of capital investment by businesses in a particular state, as summarized by our state tax wedge measure, are driven primarily by the rates of the corporate income tax and the investment tax credit (if one has been enacted) in the state. In this section, we analyze how state investment tax policies have changed over the past 40 years, both in terms of overall or average investment-related taxation, as well as in terms of the geographic distribution of such taxation.

\footnotetext{
${ }^{5}$ The effect of federal tax policy on cross-state variation in the true after-tax price of capital likely is very small, but it is not literally zero because federal tax parameters interact with state tax parameters in the formula for the after-tax price. For example, the "effective" state corporate tax rate may be a function of the federal tax rate if the state allows for the deductibility of federal taxes from state taxable income.
} 


\section{A. Growth Over Time}

State level tax policy concerning business investment has been far from stable over the past forty years. The most obvious evidence of this movement is the rise in the number of states offering investment tax credits. This rise is shown in Figure 1 (see the bars). In 1969, New York became the first state to enact an investment tax credit (ITC). 21 additional states have since enacted their own, though two states (California and Maine) later repealed their credit. ${ }^{6}$ In addition to the rising number of states offering credits, the average size (rate) of the credits, among those states that offer one, also has increased dramatically (see the line in Figure 1). The average credit rate rose from $1 \%$ in the early 1970 s to about $4 \%$ in the 2000 s.

Figure 2 shows the combined effect of the rising adoption of ITCs and the increasing rate among adopters. Specifically, the red-gray solid line in the figure shows the overall average ITC rate (i.e., the average including the zeros of the non-ITC states). The overall average increased steadily but slowly from 1968 to 1993, then increased rapidly in the late 1990s before flattening out in the 2000s.

The other main state tax parameter affecting business investment is the corporate income tax rate. We focus here on the top marginal tax rate - i.e., the rate relevant for the largest businesses - since large businesses tend to account for the bulk of investment in the U.S. The average top marginal corporate income tax rate among states, from 1964-2004, is shown in Figure 2 (dotted line). The average tax rate rose steeply from 1964 to 1972 - in large part because a number of states first adopted a corporate income tax during this period - then rose relatively slowly until 1991, and has since declined slowly but steadily.

\footnotetext{
${ }^{6}$ As noted earlier, we are including here only general, state-wide ITCs. ITCs eligible only on investment in limited geographic areas (e.g., “enterprise zones”), in specific industries, or for specific firms are excluded.
} 
As discussed in the previous section, the combined effect of state corporate income taxes and state ITCs can be assessed by the state tax wedge - the ratio of the after-tax price of capital (excluding federal and property tax components) and the pre-tax price of capital. A tax wedge of 1 represents neutral tax policy with respect to investment. Values above 1 imply tax disincentives to investment, while values below 1 imply tax subsidies. The average state tax wedge over our sample period is shown in the solid black line in Figure 2. For the purposes of display, we subtract one from the average state tax wedge in order to fit it on the same axis as the ITC rate. For example, a value of $1 \%$ translates into a state tax wedge value of 1.01 . The time series movement of the state tax wedge essentially can be characterized by three episodes. From 1964 to 1972 , the average state tax wedge increased from 1.011 to 1.018 . This increase was almost entirely due to the increase in the average corporate income tax over this period. From 1973 to 1993, the average tax wedge was roughly constant at around 1.017. This constancy was the result of a steadily increasing average corporate income tax rate being offset by a steadily increasing ITC rate. Finally, from 1994 to 2004, the average tax wedge dropped precipitously to just 1.006. As the figure clearly shows, this drop was the result of a large increase in the average ITC rate, which more than offset the slight decline in corporate tax rates during this period. The averages shown in Figure 2 are unweighted. It is informative also to consider how the time series movements in average ITC rate, corporate tax rate, and state tax wedge change if one weights states by the size of their economies. This may give a sense of the aggregate impact of state tax policy changes of special interest to national policymakers. Figure 3 shows the results of weighting by Gross State Product (from the BEA), which is available only from 1977 onward. The weighted series display the same basic patterns as the unweighted series except that the weighted-average ITC rate increases, and the weighted-average tax wedge decreases, much 
more rapidly after 1993 than indicated by the unweighted series. Also, weighting by GSP yields a large drop in the ITC series and a large spike in the tax wedge series in 2004. Both the post1993 and the 2004 changes are almost entirely explained by tax policy changes in California, whose GSP hovers between 12\% and 14\% of nationwide GSP during the sample period.

California enacted a 6\% ITC in 1994; this credit was repealed in 2004.

Whether or not one weights states by economic activity, it is clear that state taxation of business investment has declined considerably since at least the late 1970s and the decline has been primarily concentrated in the last ten years. It should be noted that our finding that the state taxation of business investment has fallen over the last few decades is consistent with the wellknown fall in state corporate tax revenues relative to business income (profits) since the early 1980s (see Fisher (2002) and Wilson (2006)). Our results suggest that state investment tax credits may play a large role in explaining this fall, though changes in the ability of businesses to shield income from reported taxable income also is likely to have been a major contributor (Cornia, Edmiston, Sjoquist, and Wallace (2005)).

\section{B. The Current Clustering of State Investment Tax Incentives Among States}

In the preceding section, we discussed how the average or overall taxation of business investment done by states has changed over the last forty years. We now turn to an investigation of how this taxation varies among states in 2004.

We begin by considering the geographic variation in state investment tax credits. Figure 4 displays a series of four maps, one for each year 1968, 1975, 1986, and 2004. In each map, states are shaded according to their ITC rate. States with no ITC are left white, other states are 
shaded according to where their ITC rate fits within four (exhaustive) categories, with darker shading indicating higher credit rates.

Focusing only on the 2004 map in the upper left part of Figure 4, we see a rather stark geographic clustering of ITCs. Aside from those in Idaho and Hawaii, ITCs essentially are clustered into four regions of the country - the Central Midwest, the Southeast, the Northeast, and the Rust Belt region of Michigan, Ohio, and West Virginia.

So state investment tax credits clearly are geographically clustered, but what about the general investment tax policy imposed by states? Figure 5 shows maps for the state tax wedge analogous to the ITC maps in Figure 4. States are shaded according to which of five, fixed categories describes their tax wedge. Darker shading indicates a lower state tax wedge, i.e., state tax policy more favorable to investment. States in white actually have a tax wedge less than or equal to one, meaning that the after-tax price of capital is equal to or less than the pre-tax price. Tax wedge less than one (i.e., a subsidy) can occur if a state has an ITC along with a zero or very low corporate tax rate.

Again, we focus for now just on the 2004 map in Figure 5. There appears to be considerable clustering in 2004. Roughly speaking, there are primarily three clusters of comparatively low state tax wedges: The Northern Plains states of Iowa, Nebraska, South Dakota, and Wyoming; the lower Northeast; and the Southeast. More formally, we note that the correlation, in 2004, between a state’s tax wedge and the average tax wedge among its bordering states ("neighbors") is $0.24(p<0.1)$. 


\section{Clustering Among States in Changes to State Investment Tax Incentives}

In the preceding two subsections, we showed that state investment tax incentives have increased over time and that, as of 2004, state investment tax incentives were clustered in certain regions of the country. Here we ask whether the timing of changes in state investment tax incentives tends to be geographically clustered.

First, we assess the extent of clustering in the enactment of state ITCs at four points in time. Given the relatively small number of observations of ITC enactment to date (22), it is difficult to statistically test whether, in a given year, the probability of a state enacting an ITC is related to whether its neighboring states have recently adopted an ITC. However, such clustering clearly is suggested by comparing the year maps in Figure 4. The enactment of ITCs by states over the last forty years can be characterized, loosely, by four "episodes": adoption in the Northeast between 1969 and 1975, adoption in the Central Midwest between 1975 and 1986, adoption in the Rust Belt between 1995 and 2003, and adoption in the Southeast in the single two-year period of 1995-96. This regional clustering of ITC enactment certainly is suggestive of tax competition among neighboring states, though it is by no means proof of tax competition. It alternatively could be explained by states responding independently to state-specific economic shocks, which happen to be spatially correlated. 
Changes in state investment tax policy, more generally, as reflected in changes in the state tax wedge, also appear to be clustered geographically. This clustering can be seen by comparing the four maps in Figure 5. It is particularly apparent for the Southeast and the Northeast. For instance, the southeast states of Tennessee, Virginia, North Carolina, South Carolina, and Georgia all had tax wedges in the middle category, 1.015 to 1.02, from 1968 to 1986; by 2004, three of these states had reduced their tax wedge below 1.015. Clustering also is illustrated well by the changes in tax wedge in the northeast. The lower northeast states of New York, Vermont, Massachusetts, Rhode Island, and Connecticut each had tax wedges in the upper half of the distribution in 1968, while the uppermost northeast states of Maine and New Hampshire had tax wedges in the lowest category. By 2004, the reverse was true: the lower northeast states were all in the lowest category of tax wedge, while the uppermost states were in the top two categories.

\section{Conclusions}

This paper investigated how tax policy at the state level with regard to investment varies across states and over time. We developed a framework for measuring state taxation of investment useful for cross-state and cross-time comparisons and compiled data on such taxation for each state plus the District of Columbia from 1964 to 2004 . Figures 1, 2, and 3 documented that state investment tax incentives have grown dramatically over the last forty years. We also presented evidence in Figures 4 and 5 of strong geographic clustering of these incentives, both in terms of their distribution in 2004 and in terms of how they have changed over time.

As mentioned in the introduction, there has been substantial debate in recent years concerning both the in-state and out-of-state effects of state investment tax incentives on 
economic activity. State policymakers, national policymakers, and the U.S. judiciary all have shown a need for careful empirical assessment of these effects. The collection, construction, and analysis of data on state investment tax policy discussed in this paper is a necessary prerequisite to such an assessment.

Our ongoing research combines the data described in this paper with state-level data on manufacturing activity and begins to evaluate the effects of state investment tax incentives on activity within and outside of the state (Chirinko and Wilson, 2006). In subsequent work, we plan to more formally evaluate the whether states are engaged in tax competition with one another. While the evidence of geographic clustering of state ITCs and state investment tax incentives more broadly is certainly suggestive of tax competition among neighboring states, one must be cautious in jumping to such a conclusion. An equally plausible alternative explains clustering by state economic shocks that are correlated within regions. Under this interpretation, clustering simply reflects that states in a region, each acting without regard to other states' policies, enact similar policies in reaction to similar economic shocks. Such an evaluation calls out for formal probit analyses and a sophisticated set of explanatory variables drawing on both economic and political forces (e.g., those described in Markusen (2006, NTA proceedings)). 


\section{References}

American Council on Intergovernmental Affairs, Significant Features of Fiscal Federalism (Washington, DC: American Council on Intergovernmental Affairs, Various Issues). URL (e.g., 1987): http://www.library.unt.edu/gpo/ACIR/SFFF/SFFF-1988-Vol-1.pdf.

Chirinko, Robert S., and Wilson, Daniel J. (2006a), "State Investment Tax Incentives: What are the Facts?" National Tax Association Proceedings of the $99^{\text {th }}$ Annual Conference on Taxation, Forthcoming.

Chirinko, Robert S., and Wilson, Daniel J. (2006b), "State Investment Tax Incentives: A ZeroSum Game?” Federal Reserve Bank of San Francisco Working Paper. December 2006.

Commerce Clearing House, State Tax Handbook (Chicago: Commerce Clearing House, Various Issues).

Cornia, Gary; Edmiston, Kelly D.; Sjoquist, David L., and Wallace, Sally. "The Disappearing State Corporate Income Tax.” National Tax Journal. 2005 Mar; 58(1):115-138.

The Council of State Governments, The Book of the States (The Council of State Governments: Lexington, Kentucky, Various Issues).

Fisher, Peter. "Tax Incentives and the Disappearing State Corporate Income Tax," State Tax Notes, March 4, 2002, pp. 767-774.

Gravelle, Jane G., The Economic Effects of Taxing Capital Income (Cambridge: MIT Press, 1994).

Hall, Robert E. and Jorgenson, Dale W. "Tax Policy and Investment Behavior.” American Economic Review. 1967 Jun; 57:391-414.

Jorgenson, Dale W., and Yun, Kun-Young, Investment Volume 3: Lifting the Burden: Tax Reform, the Cost of Capital, and U.S. Economic Growth (Cambridge: MIT Press, 2001).

King, Mervyn A., and Fullerton, Don (eds.), The Taxation of Income from Capital (Chicago: University of Chicago Press (for the NBER), 1984).

Stark, Kirk J. and Wilson, Daniel J. "What do We Know About the Interstate Economic Effects of State Tax Incentives?” Georgetown Journal of Law \& Public Policy. 2005; 4(1): 133-64.

Tax Foundation web site. URL: http://www.taxfoundation.org.

Wilson, Daniel J. “The Mystery of Falling State Corporate Income Taxes” FRBSF Economic Letter, 2006-35 (2006). 
Figure 1. The Rise and Spread of State Investment Tax Credits

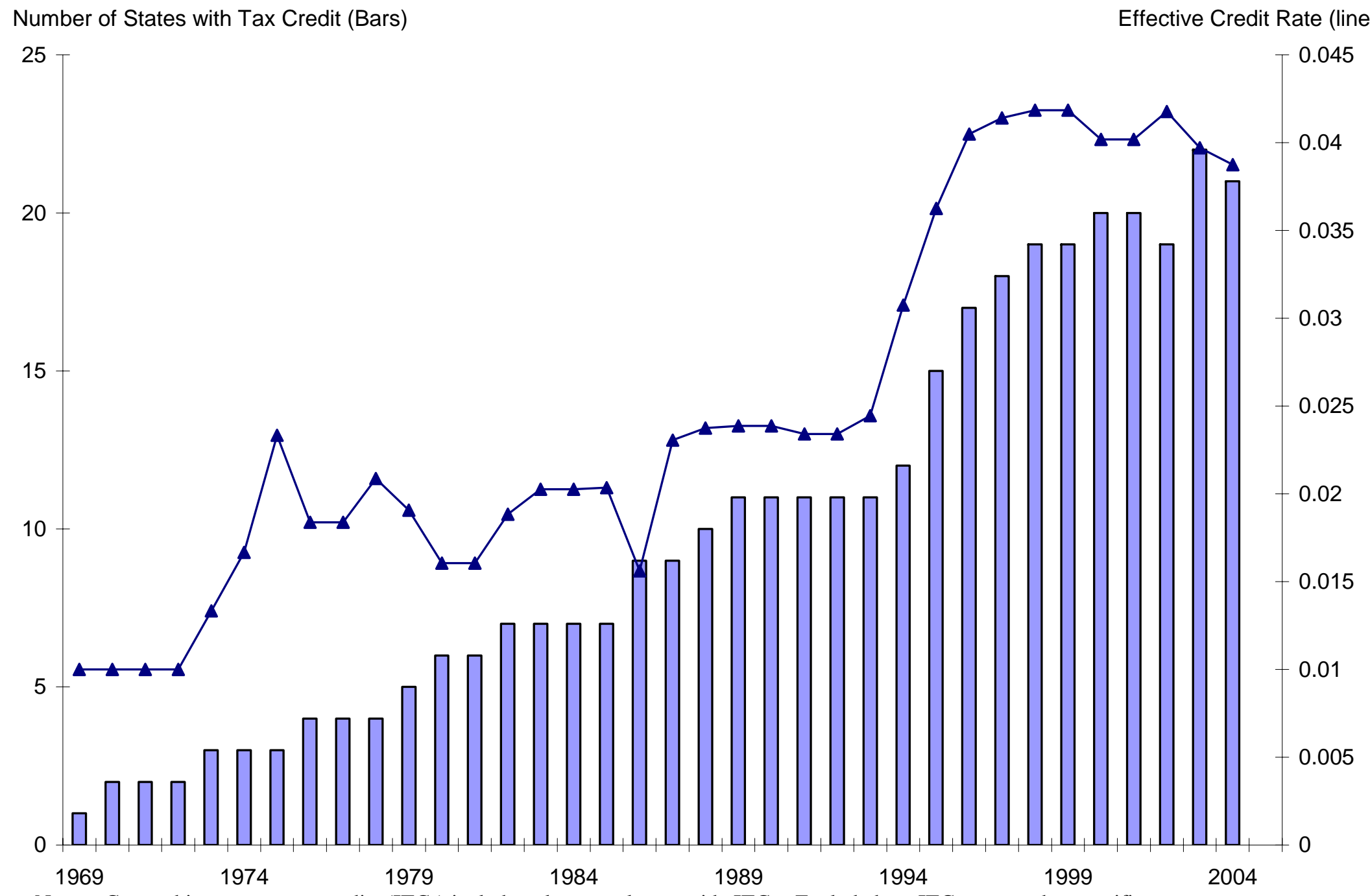

Notes: Counted investment tax credits (ITCs) include only general, statewide ITCs. Excluded are ITCs targetted at specific

geographic zones ("Enterprise" zones), specific industries, or specific companies.

Data Source: Authors' calculations based on state corporate tax forms. 
Figure 2. Average State Tax Parameters, Unweighted

1964-2004

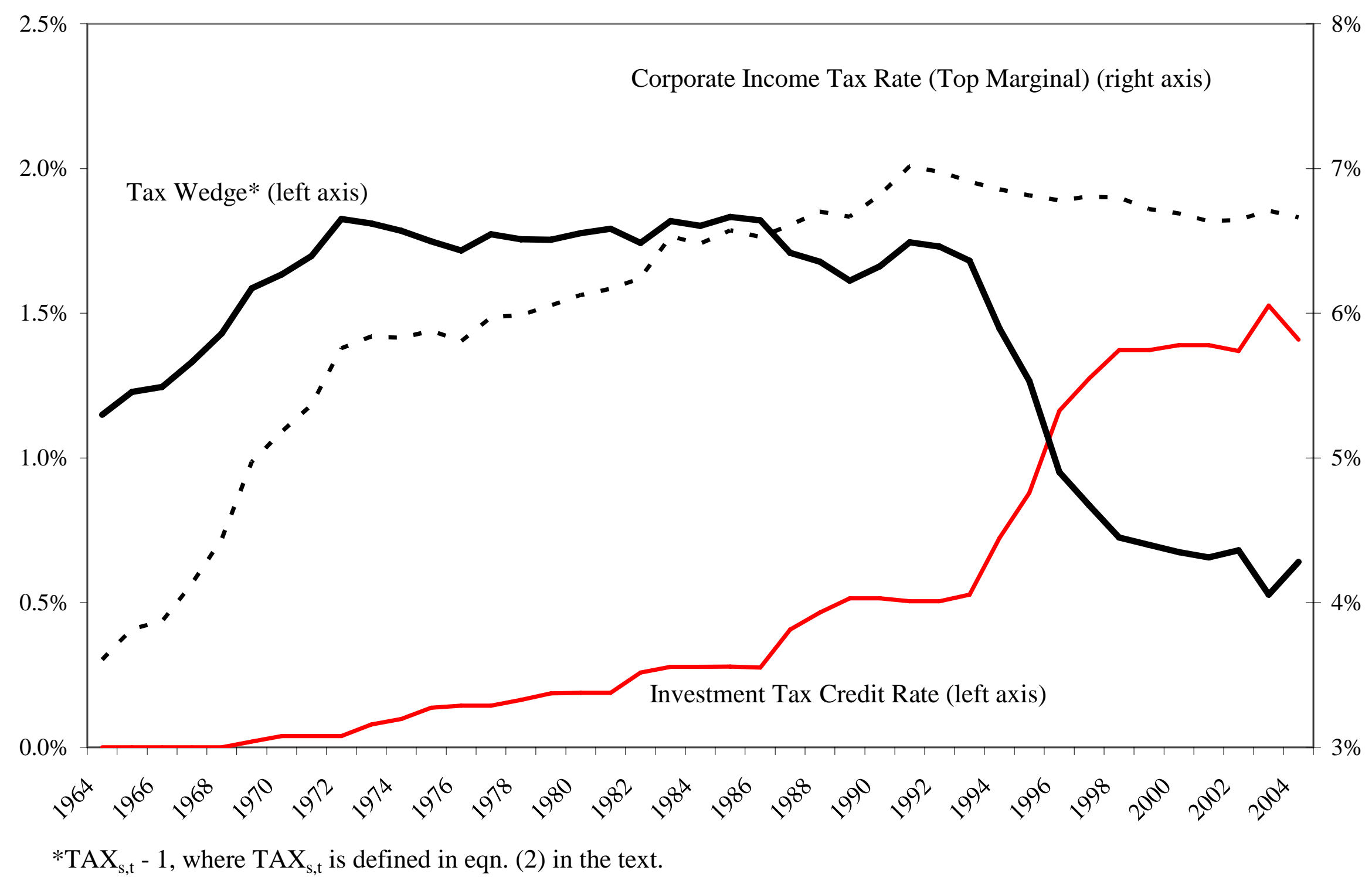


Figure 3. Average State Tax Parameters, Weighted by State GSP 1977-2004

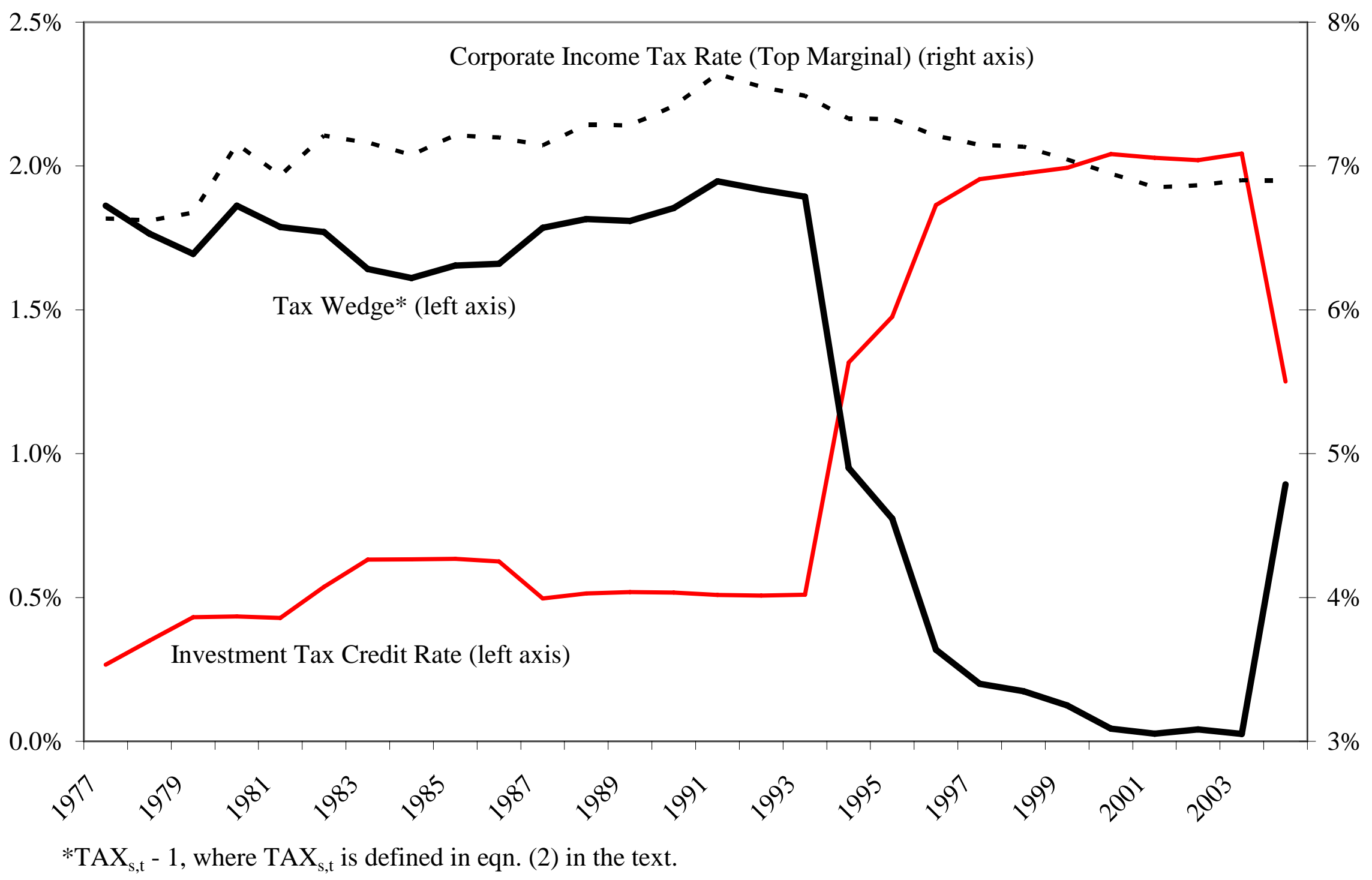


Figure 4. Investment Tax Credits by State, Various Years
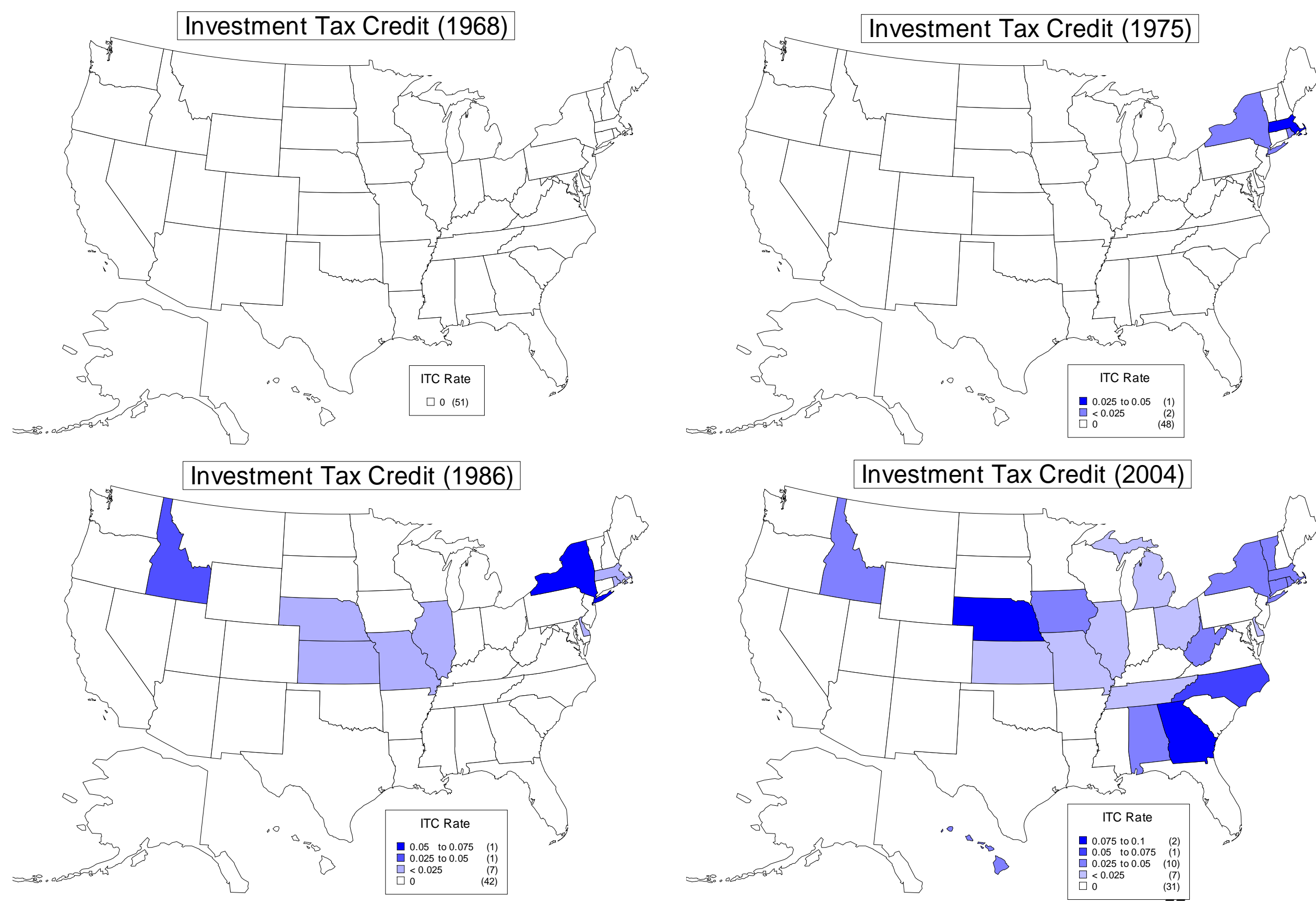
Figure 5. Tax Wedge by State, Various Years

Tax Wedge (1968)

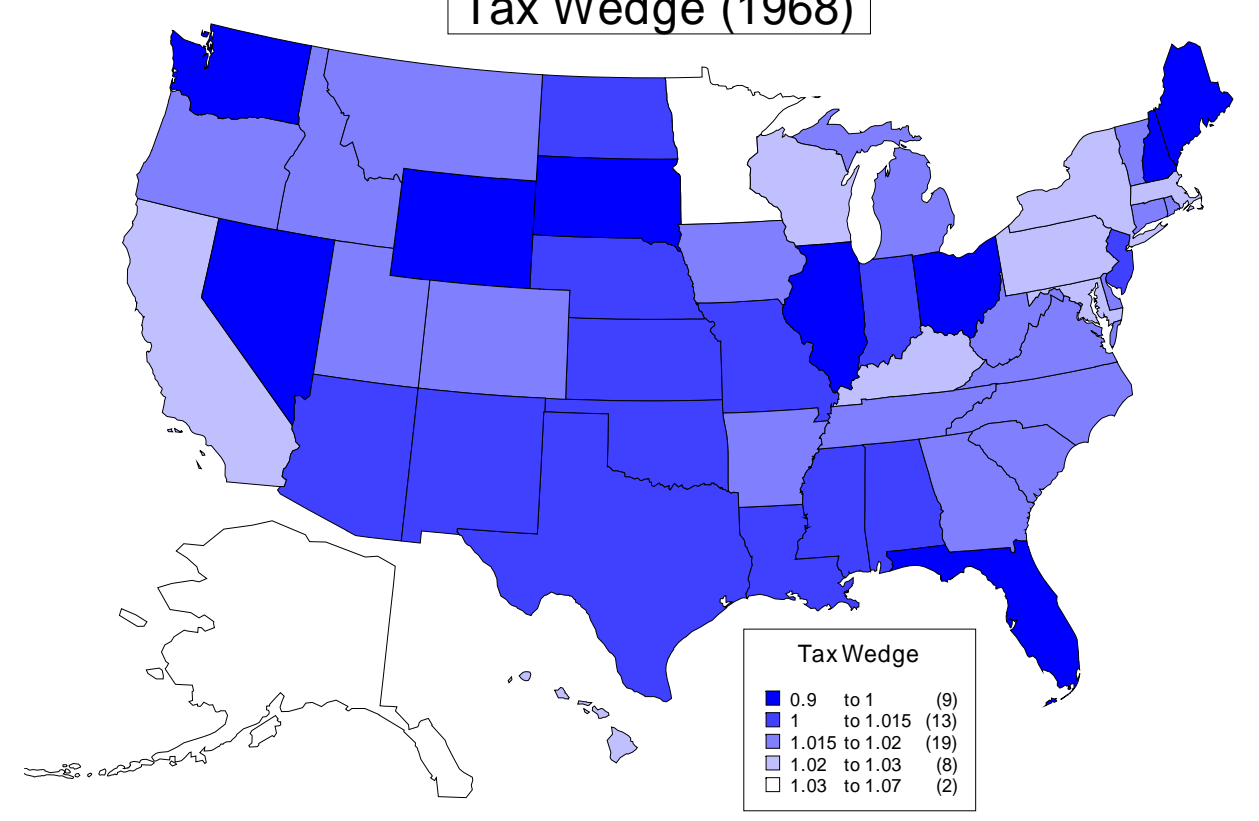

Tax Wedge (1986)

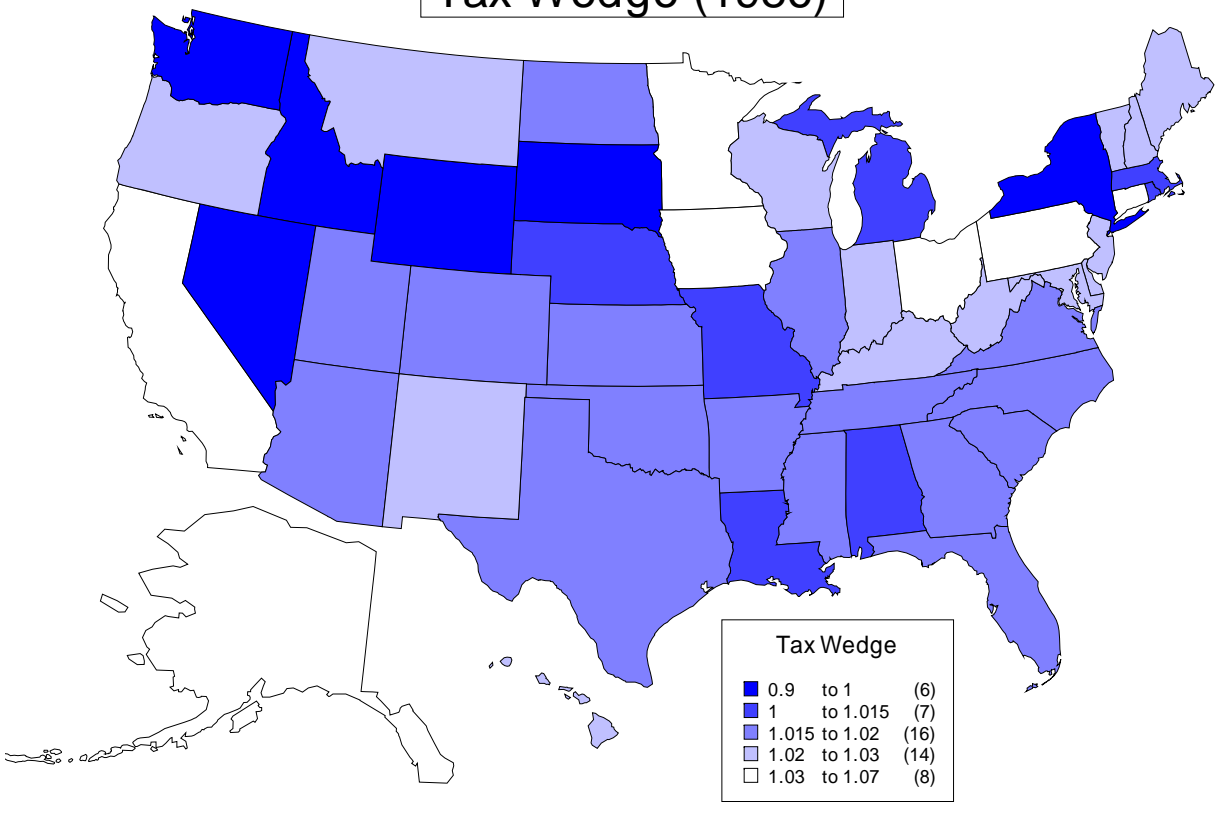

Tax Wedge (1975)

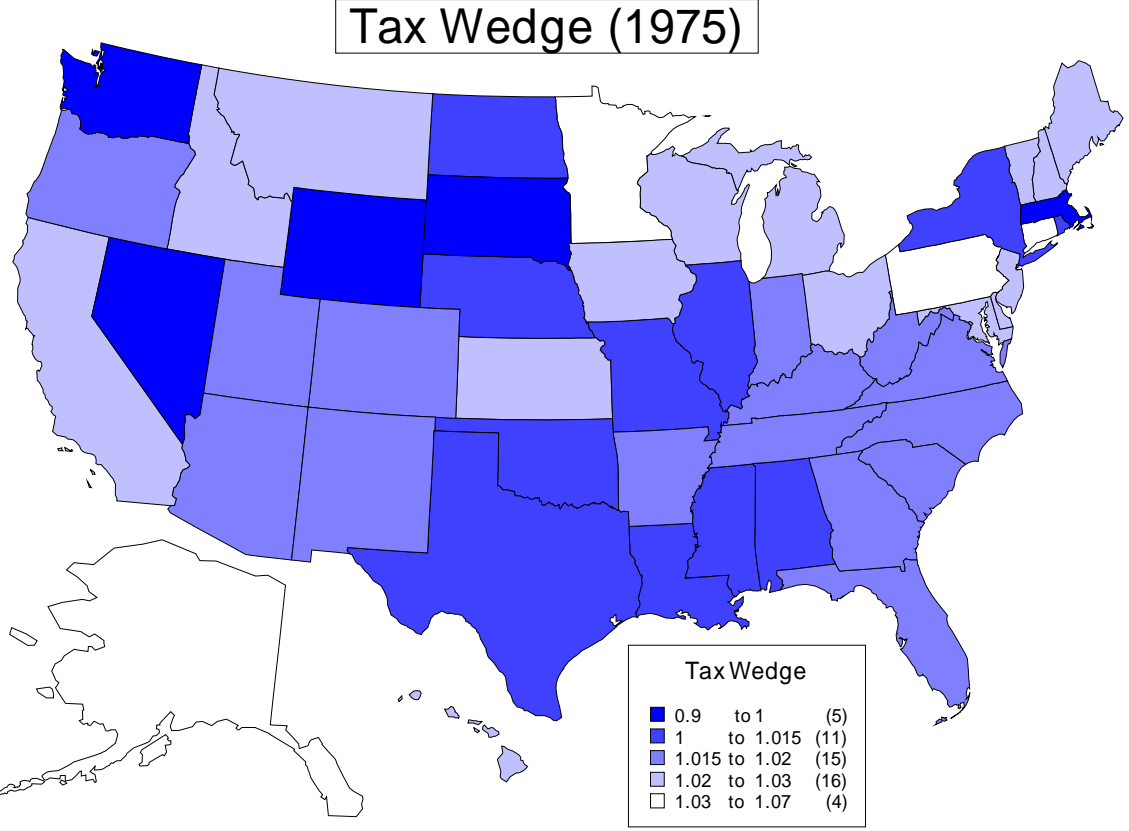

Tax Wedge (2004)

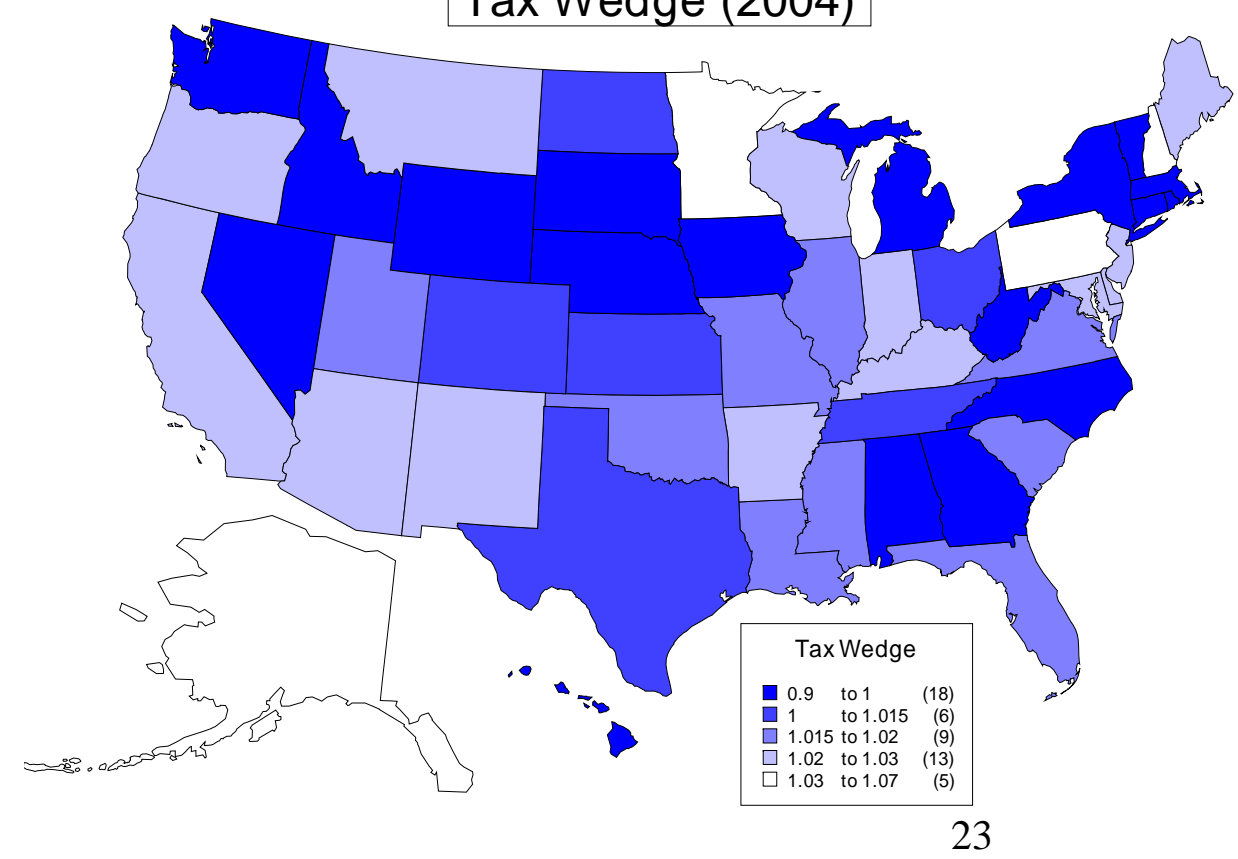

